\title{
Hubungan Mobilisasi Dini Post Sectio Caesarea (SC) dengan Penyembuhan Luka Operasi di Ruang Kebidanan RSUD dr. Fauziah Kecamatan Kota Juang Kabupaten Bireuen
}

\author{
Mobilization Relationships in Post sectio Caesarea (SC) With Healing of \\ Operating Woes in The Middle Room RSUD dr. Fauziah Kecamatan Kota \\ Juang Bireuen District \\ Sarah Nadiya*1 ${ }^{1}$ Cut Mutia ${ }^{2}$ \\ ${ }^{1,2}$ Akademi Kebidanan Munawarah, Jalan Sultan Iskandar Muda, No. 18 Kota Juang, Bireuen \\ *Korespondensi Penulis: snasarah25@gmail.com
}

\begin{abstract}
Abstrak
Menurut Profil Kesehatan Indonesia (2014) jumlah ibu dengan persalinan sectiocaesarea sebanyak 18,5\%. Di Indonesia sectiocaesarea umumnya dilakukan bila ada indikasi medis tertentu, sebagai tindakan mengakhiri kehamilan dan komplikasi. Sectiocaesarea sebanyak $25 \%$ dari jumlah kelahiran yang ada dilakukan pada ibu-ibu yang tidak memiliki resiko tinggi untuk melahirkan secara normal maupun komplikasi persalinan lain. Tujuan penelitian adalah untuk mengetahui Hubungan Mobilisasi Dini Post SC dengan Penyembuhan Luka Operasi di ruang kebidanan RSUD dr Fauziah Bireuen Tahun 2018. Jenis penelitian ini adalah penelitian analitik dengan pendekatan cross-sectional.Pengambilan sampel dilakukan secara accidental sampling dengan sampel berjumlah 40 responden. Pengumpulan data menggunakan kuesioner dan lembar observasi. Hasil penelitian sebagian besar responden tidak melakukan mobilisasi dini post sc yaitu sebanyak 23 reponden $(57,5 \%)$, faktor penyembuhan luka operasi ibu berada pada kategori baik yaitu sebanyak 24 responden (60\%). Berdasarkan hasil uji silang ibu dengan penyembuhan luka operasi yang tidak baik adalah responden yang tidak melakukan mobilisasi dini yaitu sebanyak 13 responden (32,5\%). Berdasarkan hasil uji chi square didapatkan nilai $\rho(0,031)<\alpha(0,05)$. Diharapkan hasil penelitian ini dapat menjadi masukan atau pedoman untuk mengevaluasi tentang mobilisasi dini pada ibu post sc di Ruang Kebidanan Rumah Umum Daerah dr. Fauziah Bireuen.
\end{abstract}

Kata kunci : Mobilisasi Dini Post SC, Penyembuhan Luka operasi

\begin{abstract}
According to the Indonesian Health Profile (2014) the number of mothers with sectiocaesarean deliveries was $18.5 \%$. In Indonesia, sectioocaarea is generally done if there are certain medical indications, as an act of ending pregnancy and complications. Sectiocaesarea as much as 25\% of the number of births is performed on mothers who are not at high risk for normal childbirth and other labor complications. The aim of the study was to
\end{abstract}


determine the relationship of Post SC Early Mobilization with Surgical Wound Healing in the midwifery room of the Dr. Fauziah Bireuen Hospital in 2018. This type of research is analytical research with a cross-sectional approach. Sampling is done by accidental sampling with a sample of 40 respondents. Data collection using questionnaires and observation sheets. The results of the study of the majority of respondents did not carry out early post sc mobilization as many as 23 respondents (57.5\%), the healing factor for maternal surgery was in the good category as many as 24 respondents (60\%). Based on the results of crossexamination of mothers with poor surgical wound healing, respondents who did not carry out early mobilization were 13 respondents (32.5\%). Based on the results of the chi square test, the value of $\rho(0.031)<\alpha(0.05)$ was obtained. It is expected that the results of this study can be input or guidelines for evaluating early mobilization in post sc mothers in the Midwifery Room of the Regional Public House, dr. Fauziah Bireuen.

\section{Keywords: Post SC Early Mobilization, Surgical Wound Healing}

\section{PENDAHULUAN}

Ibu pasca sectio caesarea disarankan untuk melakukan mobilisasi, tetapi pada ibu yang mengalami sectio caesarea rasanya sulit untuk melaksanakan mobilisasi karena ibu merasa letih dan sakit. Salah satu penyebabnya adalah ketidaktahuan pasien mengenai mobilisasi, untuk itu diperlukan pendidikan kesehatan tentang mobilisasi lebih maksimal dilakukan. Ibu yang mengalami sectio caesarea terkadang mengerti dalam pelaksanaan mobilisasi, namun ibu tidak mengerti apa manfaat dilakukan mobilisasi (Suririnah dalam Tri Septi Pujirahayu, 2016).

Mobilisasi merupakan suatu kebutuhan dasar manusia yang diperlukan oleh individu untuk melakukan aktivitas sehari-hari yang berupa pergerakan sendi, sikap, gaya berjalan, latihan maupun kemampuan aktifitas (Perry dalam Tri Septi Pujirahayu, 2016).

Mobilisasi pasca sectio caesarea dapat dilakukan setelah 24-48 jam pertama pasca bedah. Mobilisasi bertujuan untuk memperepat penyembuhan luka, memperbaiki sirkulasi, mencegah statis vena, menunjang fungsi pernafasan optimal, meningkatkan fungsi pencernaan, mengurangi komplikasi pasca bedah mengembalikan fungsi pasien semaksimal mungkin seperti sebelum operasi, mempertahankan konsep diri pasien dan mempersiapkan pasien pulang (Jitiwiyono dalam Tri Septi Pujirahayu, 2016).

Jika mobilisasi tidak dilakukan pada pasien pasca sectio caesarea maka akan menyebabkan bahaya fisiologis dan psikologis. Bahaya fisiologis mempengaruhi fungsi metabolisme normal, menurunkan laju metabolisme, mengganggu metabolisme karbohidrat, 
lemak dan protein menyebabkan kesetidak seimbangan cairan elektrolit dan kalsium dan dapat menyebabkan gangguan gastrointestinal seperti nafsu makan dan penurunan peristaltik dengan kontisipasi dan impaksi (Perry dalam Sri Septi Pujirahayu, 2016).

Mobilisasi juga dapat mempercepat proses penyembuhan luka, dengan melakukan mobilisasi ibu merasa lebih sehat, kuat dan dapat mengurangi rasa sakit dengan demikian ibu memperoleh kekuatan, mempercepat kesembuhan, fungsi usus dan kandung kemih lebih baik, merangsang peristaltik usus kembali normal dan mobilisasi juga membantu mempercepat organ-organ tubuh bekerja seperti semula (Hartati dalam Lina, 2017).

Banyak faktor-faktor yang mempengaruhi penyembuhan luka, akan tetapi pelaksanaan luka sangat cermat merupakan bagian paling penting dalam mengendalikan terjadinya komplikasi pada luka post operasi. Salah satu komplikasi yang sering ditemukan di rumah sakit adalah infeksi. Infeksi luka operasi merupakan infeksi yang dapat disebabkan oleh beberapa faktor antara lain yaitu mobilisasi dini post SC (Elisa dalam Lina, 2017).

Beberapa hasil penelitian yang dilakukan sebelumnya oleh Suanidar (2013) tentang hubungan mobilisasi dini post SC dengan penyembuhan luka operasi dengan jumlah pasien $45 \mathrm{ibu}$ post operasi caesarea didapatkan hasil 58,3\% yang melakukan mobilisasi dini proses penyembuhan lukanya cepat dan $81,8 \%$ yang tidak melakukan mobilisasi dini proses penyembuhan lukanya lambat. Hasil penelitian Solomon (2010), menemukan adanya perbedaan kenyamanan antara pasien pasca persalinan caesarea yang melakukan mobilisasi dini dengan yang terlambat melakukan mobilisasi (Elisa dalam Lina, 2017).

Berdasarkan Riskesdas tahun 2010, presentase persalinan dengan sectio caesarea di Indonesia masih besar yaitu 15,3\% dengan rentang tertinggi 27,2\% di DKI Jakarta dan terendah 5,5\% di Sulawesi Tenggara, sedangkan hasil Riskesdas tahun 2013 menunjukkan kelahiran dengan sectio caesarea sebesar 9,8\% dengan proporsi tertinggi di DKI Jakarta sebesar 19,9\% dan terendah di Sulawesi Tenggara Caesarea 3,3\%, sedangkan angka kejadian persalinan sectio caesarea di D.I Yogyakarta tahun 2013 diketahui mencapai 23\% (Riskesdas, 2010).

Menurut data WHO (World Health Organization), sebanyak 99\% kematian ibu akibat masalah persalinan atau kelahiran terjadi di Negara-negara berkembang yaitu Negara yang masuk dalam ASEAN (Association of South East Asian Nations) seperti Negara Indonesia. Rasio kematian di Negara-negara berkembang merupakan yang tertinggi dengan 450 kematian ibu per 100.000 kelahiran bayi hidup, jika dibandingkan denga rasio kematian ibu 
disembilan Negara maju yaitu Jepang, Amerika Serikat, Australia, Belanda, Newzealand, Kanada, Irlandia, Jerman, dan Swedia (Wahyuni dalam Rina Kundre, 2012).

Salah satu tujuan pembangunan Sustainable Development Goals (SDGs) 2015 adalah perbaikan kesehatan maternal. Kematian maternal dijadikan ukuran keberhasilan, terhadap pencapaian target SDGs yaitu penurunan $75 \%$ rasio kematian maternal $75 \%$ rasio kematian maternal. Frekuensi dilaporkan berkisar antara 0,3\%-0,7\% di Negara-negara sedang berkembang, sedangkan di Negara-negara maju angka tersebut lebih kecil yaitu 0,05\%-0,1\%. Berdasarkan data yang diperoleh Indonesia menjadi peningkatan angka sectio caesarea disertai kejadian infeksi luka post SC sekitar 90\% dari morbiditas pasca operasi disebabkan oleh infeksi luka setelah operasi (Kemenkes RI, 2016).

Sedangkan menurut Profil Kesehatan Indonesia (2014) jumlah ibu dengan persalinan sectio caesarea sebanyak 18,5\%. Di Indonesia sectio caesarea umumnya dilakukan bila ada indikasi medis tertentu, sebagai tindakan mengakhiri kehamilan dan komplikasi. Selain itu sectio caesarea juga menjadi alternatif persalinan tanpa indikasi medis karena dianggap lebih mudah dan nyaman. Sectio caesarea sebanyak $25 \%$ dari jumlah kelahiran yang ada dilakukan pada ibu-ibu yang tidak memiliki resiko tinggi untuk melahirkan secara normal maupun komplikasi persalinan lain (Depkes, 2014).

Menurut Profil Kesehatan Provinsi Aceh tahun 2013, angka kematian ibu sebanyak 174 kasus dengan rincian 45 kematian pada masa kehamilan, 69 kematian pada masa persalinan, 60 kematian pada masa nifas. Angka kematian bayi 1,075 (11,8\%) dari seluruh bayi di provinsi aceh dengan rincian 526 jumlah kematian bayi laki-laki dan 549 jumlah kematian bayi perempuan. Sedangkan jumlah dengan sectio caesarea sebanyak 52,7\% (Dinkes Provinsi Aceh, 2013).

Dari survey awal yang penulis lakukan di RSUD dr. Fauziah Bireuen, diperoleh data pada tahun 2018 Pasien post sectio caesarea yang dirawat di ruang kebidanan pada bulan Januari sampai Mei sebanyak 162 ibu post partum sectio caesarea. Dari 10 orang ibu postpartum hanya 3 orang yang melakukan mobilisasi dini sedangkan 7 orang lainnya tidak melakukan mobilisasi dini, Peneliti melihat perbedaan waktu kesembuhan luka cepat pada pasien post sectio caesarea berjumlah 3 orang dan kesembuhan luka lambat berjumlah 7 orang. 
Berdasarkan latar belakang tersebut diatas maka yang menjadi rumusan masalah dalam penelitian ini adalah apakah mobilisasi dini Post SC berhubungan dengan penyembuhan luka Operasi di Ruang Kebidanan RSUD dr. Fauziah Bireuen tahun 2018.

Tujuan penelitian ini Untuk Mengetahui Hubungan Mobilisasi Dini Post Sectio Caesarea Dengan Penyembuhan Luka Operasi di Ruang Kebidanan RSUD dr. Fauziah Bireuen.

\section{METODE PENELITIAN}

Penelitian ini menggunakan survey analitik dengan pendekatan cross sectional. Lokasi penelitian di RSUD dr. Fauziah Kecamatan Kota Juang Kabupaten Bireuen. Waktu penelitian ini dilakukan pada bulan Maret hingga Mei 2018. Populasi dalam penelitian ini adalah seluruh ibu yang melahirkan dengan sectio caesarea yang terdapat di RSUD dr. Fauziah Kecamatan Kota Juang Kabupaten Bireuen. Sampel dalam penelitian ini adalah keseluruhan dari populasi yang berjumlah 40 responden. Data dianalisis secara univariat dan bivariat dengan menggunakan uji Chi-Square pada taraf kepercayaan $95 \%(\mathrm{p}<0,05)$.

\section{HASIL DAN PEMBAHASAN}

Analisis Bivariat digunakan untuk mengetahui hubungan antara varibel independen yaitu Mobilisasi Dini Post Sectio Caesarea dengan variable dependent yaitu Luka Operasi . Dengan menggunakan chi-square pada tingkat kemaknaan $95 \%$ atau nilai $(\alpha=0,05$. Bila menunjukkan nilai $\mathrm{p} \leq 0,05$ artinya ada hubungan bermakna atau signifikan.

Tabel 1. Uji Silang Mobilisasi Dini Post SC dengan Penyembuhan Luka Operasi di Ruang Kebidanan Rumah Umum Daerah dr. Fauziah Bireuen Tahun 2018

\begin{tabular}{|c|c|c|c|c|c|c|c|c|c|}
\hline \multirow{3}{*}{ No } & \multirow{3}{*}{$\begin{array}{l}\text { Mobilisasi Dini } \\
\text { Post SC }\end{array}$} & \multicolumn{4}{|c|}{$\begin{array}{c}\text { Penyembuhan Luka } \\
\text { Operasi }\end{array}$} & \multirow{3}{*}{$\Sigma$} & \multirow{3}{*}{$\%$} & \multirow{3}{*}{$\mathbf{P}$} & \multirow{3}{*}{$\alpha$} \\
\hline & & \multicolumn{2}{|c|}{ Baik } & \multicolumn{2}{|c|}{$\begin{array}{c}\text { Tidak } \\
\text { Baik }\end{array}$} & & & & \\
\hline & & Jlh & $\%$ & Jlh & $\%$ & & & & \\
\hline \multirow{3}{*}{$\begin{array}{l}1 \\
2\end{array}$} & Melakukan & 14 & 35 & 3 & 7,5 & 17 & 42,5 & \multirow[b]{2}{*}{0,031} & \multirow[b]{2}{*}{0,05} \\
\hline & $\begin{array}{l}\text { Tidak } \\
\text { Melakukan }\end{array}$ & 3 & 25 & 13 & 32,5 & 23 & 57,5 & & \\
\hline & Jumlah & 24 & 60 & 16 & 40 & 40 & 100 & & \\
\hline
\end{tabular}


Berdasarkan tabel diatas, mayoritas responden yang penyembuhan luka operasi tidak baik adalah responden yang tidak melakukan mobilisasi dini yaitu sebanyak 13 responden $(32,5 \%)$. Mayoritas responden yang baik penyembuhan luka operasi adalah responden dengan melakukan mobilisasi dini yaitu sebanyak 14 responden (35\%). Hasil uji statistik chi-square antara mobilisasi dini post SC dengan penyembukan luka operasi diperoleh nilai Asymp. Sig 2-side $(0,031)<\alpha(0,05)$, yang bermakna Ha diterima dan $\mathrm{H}_{0}$ ditolak. Maka ada hubungan antara mobilisasi dini post SC dengan penyembukan luka operasi di Ruang Kebidanan Rumah Umum Daerah dr. Fauziah Bireuen.

Hasil penelitian yang telah dilakukan oleh peneliti tentang hubungan antara mobilisasi dini post SC dengan penyembukan luka operasi di Ruang Kebidanan Rumah Umum Daerah dr. Fauziah Bireuen Tahun 2018, dapat dilihat bahwa umumnya ibu mempunyai karakteristik yang pada umumnya berada pada golongan umur > 30 tahun, responden sebagian besar dalam kategori tidak bekerja dan sebagian besar responden mempunyai tingkat pendidikan yang menengah.

Berdasarkan hasil penelitian maka dapat diketahui bahwa mayoritas responden yang penyembuhan luka operasi kurang baik adalah responden yang tidak melakukan mobilisasi dini yaitu sebanyak 13 responden (32,5\%). Mayoritas responden yang baik penyembuhan luka operasi adalah responden dengan melakukan mobilisasi dini yaitu sebanyak 14 responden (35\%). Dari hasil pengujian statistik dapat diperoleh nilai $\mathrm{p}$ value $(0,031)<\alpha$ $(0,05)$, sehingga ada hubungan bermakna antara mobilisasi dini post SC dengan penyembukan luka operasi di Ruang Kebidanan Rumah Umum Daerah dr. Fauziah Bireuen Tahun 2018.

Hasil penelitian ini tidak sejalan dengan hasil penelitian yang dilakukan oleh Harfa Aini (2012) dengan judul hubungan mobilisasi dini pada ibu post sc (section caesarea) dengan proses penyembuhan luka operasi Di Ruang Kebidanan Rumah Sakit Tk.III Kesdam IM Banda Aceh dengan hasil penelitian bahwa tidak ada hubungan antara mobilisasi dini pada ibu post section caesarea dengan proses penyembuhan luka operasi ( $p$ value $=1,000$ ).

Menurut Manuaba (2010), dengan adanya mobilisasi dini secara langsung berdampak pada akselerasi proses penyumbuhan post partum hasil penelitian yang dilakukan Jensen Situmarong (2010) menyebutkan bahwa ibu post section caesarea yang melakukan mobilisasi dini dapat mempercepat proses penyembuhan luka. Sejalan dengan penelitian yang dilakukan oleh Purnawati (2014), yang menemukan bahwa mobilisasi dini pada ibu post partum efektif terhadap percepatan proses penyembuhan luka sectio caesarea. 
Adanya responden dengan mobilisasi dini yang kurang baik tetapi luka post sectio caesarea dapat pulih dengan baik dapat disebabkan oleh faktor lain yang mempengaruhi pemulihan luka post sectio caesarea. Faktor tersebut misalnya nutrisi ibu dan keadaan luka. Responden dengan asupan nutrisi yang cukup, maka penyembuhan luka akan cepat. Nutrisi merupakan faktor yang penting dalam proses penyembuhan luka. Terutama luka jahitan setelah operasi. Nutrisi yang terkandung dalam makanan seperti sayur dan buah-buahan yang mengandung vitamin $\mathrm{C}$, serta telur dan susu yang mengandung vitamin $\mathrm{A}$ dan zinc merupakan zat yang membangun jaringan ikat, pertumbuhan kulit dan pengeringan luka sehingga mempercepat penyembuhan luka.

Salah satu pelaksanaan mobilisasi dini adalah latihan pernafasan dilakukan ibu sambil tidur terlentang sedini mungkin. Latihan pernafasan dilakukan agar ibu rileks dalam posisi istirahat sehingga ibu mampu mensugestikan diri untuk melakukan mobilisasi dini. Peneliti menganjurkan ibu untuk latihan mengangkat kaki secara lurus, melenturkan lutut dan kaki 4 jam setelah operasi. Upaya ini dilakukan untuk meningkatkan kelancaran peredaran darah sehingga dapat mempertahankan fungsi tubuh dalam memenuhi kebutuhan gerak harian.

Menurut asumsi peneliti, mobilisasi dini hanya salah satu faktor penghambat penyembuhan luka. Walau sudah menjalani mobilisasi sesuai prosedur yang disepakati rumah sakit, beberapa responden masih saja mengalami penyembuhan luka yang tidak baik, yaitu seperti luka teraba hangat ketika di sentuh pada hari kedua setelah persalinan. Penyembuhan luka juga dapat dipengaruhi oleh beberapa faktor seperti kebersihan luka, nutrisi, status gizi, dan personal hygiene. Kebersihan diri seseorang akan mempengaruhi proses penyembuhan luka, karena kuman setiap saat dapat masuk melalui luka bila kebersihan diri kurang.

\section{KESIMPULAN}

Kesimpulan penelitian ini adalah terdapat hubungan antara mobilisasi dini post sectio caesarea (SC) dengan penyembuhan luka operasi di Ruang Kebidanan Rumah Umum Daerah dr. Fauziah Bireuen.

\section{SARAN}

Diharapkan hasil penelitian ini dapat menjadi masukan atau pedoman untuk mengevaluasi tentang mobilisasi dini pada ibu post sc di Ruang Kebidanan Rumah Umum Daerah dr. Fauziah Bireuen. 


\section{DAFTAR PUSTAKA}

Anik Maryunani, (2011). Keterampilan Dasar Praktik Klinik Kebidanan. Trans Info Media : Jakarta

HarfaAini. (2012) Mobilisasi Dini Pada Ibu Post Sc (Section Caesarea) Dengan Proses Penyembuhan Luka Operasi Di RuangKebidananRumahSakitTk.IIIKesdam IM Banda Aceh

Iman. (2017). Panduan PenyusunanKaryaTulisIlmiahBidangKesehatan. Bandung :CitaPustaka Media Perintis.

Iman. (2015). Pemanfaatan SPSS DalamBidangKesehatan. Bandung :CitaPustaka Media Perintis.

Irma P. Arisanty, (2013). Konsep Dasar Manajemen Perawatan Luka. EGC : Jakarta

Ismail, (2008). Luka Operasi. Diambil dari http://edukasiII.blogspot.comDiakses oleh Nailur Rahmi. Diakses April 2018

Jensen Situmarong, (2010). Diambil dari Jurnal Zahrati Fauza tentang Hubungan Mobilisasi Dini pada Post Partum dengan SC terhadap Proses Percepatan Pemulihan Post Partum

Lina. (2017). Faktor yang Mempengaruhi Proses Penyembuhan Luka pada Pasien Post Operasi Seksio Seasarea di Ruang Nifas

Noerni Rachmawati, (2016). Faktor yang Berhubungan dengan Pelaksanaan dini pada Pasien Post Apendiktomi di Bangsal Anggrek RSUD dr Soediran Mangun Sumarso Wonogiri

Notoatmodjo. (2010),Metode PenelitianKesehatan. Jakarta : Rineka Cipta

Notoatmodjo. (2012), Ilmu Kesehatan Masyarakat, Jakarta : Rineka Cipta

Manuaba, Ida Bagus Gde. (2010). Kepaniteraan Klinik Obstetri dan Ginekologi. Jakarta: EGC.

Oshigita, (2014). Mekanisme Luka Operasi. Diambil dari http://www.scrib.comDiakses oleh Nailur Rahmi. Diakses April 2018

Purnawati, Jolanda. (2014). Efektivitas Mobilisasi Dini pada Ibu Post Partum terhadap Percepatan Proses Penyembuhan Luka Sectio Caesarea Fase Inflamasi di RSUD Sanggau Tahun 2014. Skripsi Mahasiswa Prodi Keperawatan, Fakultas Kedokteran Universitas Tanjungpura, Pontianak.

Reni Yuli Astutik, (2015). Asuhan Keperawatan Masa Nifas dan Menyusui. Trans Info Media : Jakarta Timur

Rina Kundre. (2015). Hubungan Tingkat Pengetahuan dengan Mobilisasi Dini pada Ibu Nifas di Puskesmas Likupang Timur Kecamatan Likupang Timur Volume Nomor 1

Sri Mahmudah. (2015). Hubungan Mobilisasi Dini dengan Pemulihan Luka Post SC di Rumah Sakit Penembahan Senopa Bantul tahun 2015

Tri Septi Pujirahayu. (2016) Analisis Asuhan Keperawatan Pada Klien Dengan Masalah Hambatan Mobilitas Fisik di Ruang Flamboyan RS Margono Soekarto Purwokarto. 
Tupriliany Danefi, (2016). Hubungan Mobilisasi Dini Post SC dengan Penyembuhan Luka Operasi di Ruang Nifas RSU dr Soekarjo Kota Tasikmalaya tahun 2015. Diambil dari Jurnal "Midwife Journal" Volume 2 No 1 Januari 2016

Vivian. (2011). Asuhan Kebidanan pada Ibu Nifas. Salemba Medika : Jakarta Selatan

Yusuf Sinaga. (2009). Penyembuhan Luka. Diambil dari http://yusuf.sinaga.wordpress.comDiakses April 2018

Zahrati Fauza. (2013). Hubungan Mobilisasi Dini pada Post Partum dengan SC terhadap Proses Percepatan Pemulihan Post Partum di Ruang Kebidanan RSUDZA Banda Aceh 